\title{
Optimization of achievement motivation to improve long jump performance
}

\author{
Tjung Hauw Sin ${ }^{*}$, Budi Indra Ruslin ${ }^{2}$ \\ ${ }^{12}$ Universitas Negeri Padang \\ ${ }^{*}$ Corresponding author, ఏ'e-mail: tjh_sin@yahoo.com
}

\begin{abstract}
This study aims to reveal the achievement motivation of the athlete's long jump ability. This is so motivated by the observations of the athlete's performance is still not under the reality. Achievement of an athlete long jump is still lower than the previous year and declines. One reason is the low motivation of athlete achievement. This phenomenon is an attraction for writers to examine related to the optimization of achievement motivation to improve the performance of long jump athletes. This research is the quasi-experiment. Sampling is done by purposive random sampling. The sample size was 32 people out of 58 athletes. Achievement motivation data got through the use of instruments in the form of a questionnaire. Validity analysis is to test used product-moment correlation SPSS version 20.00 and data analysis with T-Test. The results showed that there was a significant difference in ability of long jump athletes with high achievement motivation compared to low achievement motivation.
\end{abstract}

Keywords: motivation, long jump, athlete, achievement

How to Cite: Sin, TH., Ruslin, BI., (2018). Optimization of achievement motivation to improve long jump performance. Couns-Edu: International Journal of Counseling and Education, 3(1): pp. 34-40. DOI: https://doi.org/10.23916/0020180313810

(1) This is an open access article distributed under the Creative Commons Attribution License, which permits unrestricted use, distribution, and reproduction in any medium, provided the original work is properly cited. (C2017 by author and Indonesian Counselor Association (IKI).

\section{Introduction}

The long jump is one of the jumping numbers in an athletic branch which of consist the jumping jump, high jump and high pole jump (Abbas, 2017; Muhajir, 2007b; Purba, 2014; Septianto, 2015). The goal of the long jump is to jump as far as by moving the whole body from the points certain to another point by running as fast as possible and then refusing, floating through the air and landing. Long jump is a form of jumping foot movement upward to bring the weight as long as possible on the air or fly on the air that is done and by doing repulsion on one foot to reach the far distance (Syafruddin, 2011). The long jump is an athletic number where the athlete combines speed, power and agility in an effort to land as far as from the point of repulsion (Ho \& Chang, 2013; Kamnardsiria et al., 2015; Pradon et al., 2014; Yadav, 2015).

Prefix is a start movement in the form of running to get the speed at which time will perform repulsion or leap. The purpose of the prefix is to gradually accelerate to a maximum controlled speed at take-off. The higher the speed outcurve, the more jumping distance that will be achieved (Yadav, 2015). The speed obtained from the prefix is called the horizontal velocity, which is very useful to help the force at the time of repulsion upwards.

Cultivation or support is a rapid movement between running, prefix and hovering. According to Muhajir, footstool or foot, repulsion must be strong to achieve high enough leaps without losing speed 
forward (Muhajir, 2007a). The aim of repulsion is to create vertical impulses through the athlete's center of gravity while maintaining balance and control (Yadav, 2015). Placing your legs with your knees bent to do repulsion with straight legs. This process is enhanced by lifting the arms and legs swing (Seyfarth, Friedrichs, Wank, \& Blickhan, 1999). In addition Wakai, distance repulsion is the horizontal distance between the starting line and the rejection board the power of the jumper at the time of hiking (Wakai \& Linthorne, 2005). The distance from the flight is horizontal. The distance of the center jumper moves from the moment of take-off to Direct landing.

In a squat style, while floating through the air, there are things to be noticed by the athlete. First, the body bounces forward, then the arms straight ahead, and the last two feet meet in front. The purpose at this stage is to resist the body's natural rotation from taking off while maintaining an effective landing position (Yadav, 2015). At the time of landing the jumper should be able to cultivate his arm extending far forward by not losing the balance within the body (Adisasmita, 1992). On landing, the primary purpose of the jumper is not to fall back on the landing pit (Yadav, 2015). The jump is measured from the location where the body contacts the sand closest to the takeoff point. When jumping at a low takeoff angle, the athlete has a high horizontal speed on landing, and therefore, he can land with his feet deep in front of his body without risking falling back after landing (Linthorne, Guzman, \& Bridgett, 2005). At this moment, the feeling arises that the body will fall backward. To prevent it, the weight should be carried forward by bending the body, so that the body and knees are almost docked also assisted with a hand forward. Based on observations of athletes long jump performance is still not under a reality. Achievement of a long jump athlete is still low even tends to decline from year to future years. One cause is a low motivation of athlete achievement. This is an attraction to be studied.

The long jump is one sport who aims to jump as far as by moving the whole body from a certain point to another, whose execution begins by running as fast as possible and then refusing, floating through the air and landing. State Junior High School 3 Batang Kapas is one of the official educational institutions that have a role in fostering and developing sports in education from an early age. In the effort of developing and enhancing the ability of the long jump. There are several factors that affect the ability of a long jump. One of the factors to achieve achievement in sports, long jumps to watch out for is the speed, explosive power over the leg muscles, the shape and coordination of motion (Yani, 2015). To improve the performance of long jump should also pay attention to the method of exercise used, motivation of athlete achievement.

Motivation is one of the factors needed by athletes in the training process. Motivation comes from the Latin word "Movere" which means to move (Satiadarma, 2000). Alderman in Satiadarma defines motivation as a tendency to behave selectively to a certain direction that is controlled by certain consequences, and that behavior will persist until the objectives of behavior can be achieved (Satiadarma, 2000). Meanwhile, according to Setyobroto, motivation is the process of actualizing the source of the driving force, and the driving behavior of individuals meet the need to achieve certain goals (Setyobroto, 2005).

Motivation is a fundamental mental skill that must be possessed by the athlete. Motivation that must be owned by athlete is achievement motivation. According to Komarudin, achievement, motivation is essentially a desire, desire, and willingness, and the impetus to excel is to surpass the achievements that have been achieved on their own or achievements that have been achieved by others (Komarudin, 2013). Furthermore, explained Husdarta, achievement motivation is an impulse that occurs within the individual to always improve a certain quality with the best or more than usual (Husdarta, 2011). Athletes with achievement motivation will pace with excellence either self-superiority, other's excellence, even to achieve excellence in performing tasks within the process of training and in the process of competition (Komarudin, 2013).

The phenomenon in the field that the research findings explain that the decrease in achievement motivation one of which is caused by the factor where the athlete lacks the belief in his ability, in other words, low self-efficacy athletes (Choirul Anam, 2007). Anwar's study found that direct evaluation affected increasing athlete's motivation (Anwar, 2015). Factors that affect the athlete's long jump speed are one of the motivation (Yunus, Saripin, \& Agust, 2018).

Based on the above opinion can be explained that the motivation of achievement is the encouragement that comes from the individual self to achieve the goals that have been determined and 
always improve certain qualities of the best or more than usual. Thus one form of encouragement by individuals in achieving a goal in an activity is called a strong motivation foundation. In addition, motivation is the impetus in a person to try to make changes in behavior better. In the process of motivational exercise is needed by an athlete, the stronger motivation or encouragement that occurs from within the self-will be the greater the likelihood of success in achieving a goal.

The impulse coming from outside is usually given by the closest people, such as coach, family, or girlfriend. Besides that, encouragement can also come from existing facilities and infrastructure, or it could be a stimulus provided by the trainer such as bonuses if able to reach the target or punishment if not reach the target. Based on some theories above can be concluded that achievement motivation is an impulse that exists in the individuals associated with achievement, namely the drive to master, manipulate and regulate the social and physical environment, overcome barriers and maintain high-quality work, an attempt to create an action that is more than the deed done before and outperforms the actions of others.

According to Mc Clelland factors that affect the achievement motivation is to have self-confidence, have responsibilities in situations that can be controlled, choosing goals to achieve goals that challenge maximum effort, there are feelings of anxiety because pressed time, which is faster when compared to individuals who have low achievement motivation, trying to get feedback from the work and never give up (Subowo, Martiarini, \& Budi, 2009). In addition, Martaniah mentions that achievement motivation consists of aspects such as Likes to try to work hard, Anticipate against failure, Enterprises surpass achievements ever achieved, Competence to surpass the achievements of others, Perfection in completing tasks, Belief in self-own (Martaniah \& Monks, 1982).

Based on the description above can be concluded that many factors support one's motivation to excel. Therefore, as an educator, a coach should understand every background tofor the problem, so when accompanying someone less motivated to perform the trainer can make the treatment and make someone eager to do better. The hope of everyone who in doing an exercise wants to achieve a goal of training and bring results that maximize and satisfy even achieveRepeated Stem high achievement.Repeated Stem However, not everyone who can do and achieve results as expected, all of which will depend upon everyone. The results of maximum practice will be realized well if the motivation achievement exists and arises from a person.

\section{Method}

This research type is quasi-experiment (Campbell \& Stanley, 2015; Cook, 2015; White \& Sabarwal, 2014) to see the difference of performance of long jump athletes of SMP Negeri 3 Batang Kapas between a group with high achievement motivation with a low achievement motivation group. This research was conducted at the sports field of SMP Negeri 3 Batang Kapas. Population in this study amounted to 58 people, and Samples amounted to 32 people taken by purposive sampling technique. To obtain the preliminary data required for this study is to measure the achievement motivation level of with a long jump test in accordance to the standard of all Indonesian athletics unity (PASI). Further measured the level of achievement motivation athletes with a questionnaire motivation achievers. Data analyzed used $\mathrm{T}$ Tes.

\section{Results and Discussion}

Based on the experimental research design undertaken, there are two sets of data that will be described separately.

After obtaining the data of athlete achievement motivation level, then sequencing the motivation score from the highest to the lowest. To determine the high and low category a score for both treatment groups can be done by dividing group members by percentage technique. According Miller, the percentage technique in question is to set $27 \%$ of the upper bound representing the high score group and $27 \%$ of the lower bound to represent the low score group (Atmaja \& Tomoliyus, 2015). Subsequently, the sample in each group was obtained from $(27 \%$ of $58=15.66)$ rounded to 16 people. Subject members whose scores are above and below that categories are not within in the sample. Overall, the subjects involved as the study sample amounted to 32 people, 16 for for the group with high achievement motivation and 16 for for 
the group with low achievement motivation. The data from the research analyzed as a analysis analysis of normality test lilliefors test and homogeneity test of variance with $F$ of of the level of trust $\alpha=0,05$.

Table 1. Long Jump Performance Data

\begin{tabular}{ccccccc}
\hline No & Group & N & High Scores & Lowest Score & Average & $\begin{array}{c}\text { Standard } \\
\text { Deviation }\end{array}$ \\
\hline $\mathbf{1}$ & High motivation & 32 & 410 & 350 & 387,69 & 18,63 \\
$\mathbf{2}$ & Low motivation & 32 & 400 & 320 & 361,63 & 22,94 \\
\hline
\end{tabular}

The result of hypothesis testing showed that the score from the group long jumps ability on high achievement motivation was significantly different from the group on low achievement motivation so that the hypothesis for this research was accepted empirically, based on the average calculation then obtained the average ability of the long jump group on achievement motivation high of 387.69 , while the average group on the low achievement motivation of 361.63 , so high achievers motivation does give a better influence upon the ability of long jump athletes than low achievement motivation.

Distribution of performance data long jumps in translate in frequency distribution table below:

Table 2. Distribution of remote jump performance data

\begin{tabular}{|c|c|c|c|c|}
\hline Interval Class & High motivation & $\mathbf{P}$ & Low motivation & $\mathbf{P}$ \\
\hline$(320-335)$ & 0 & $0.00 \%$ & 2 & $12.50 \%$ \\
\hline$(336-351)$ & 1 & $6.25 \%$ & 5 & $31.25 \%$ \\
\hline$(352-367)$ & 2 & $12.50 \%$ & 3 & $18.75 \%$ \\
\hline$(368-383)$ & 3 & $18.75 \%$ & 3 & $18.75 \%$ \\
\hline$(384-399)$ & 4 & $25.00 \%$ & 2 & $12.50 \%$ \\
\hline$(400-415)$ & 6 & $37.50 \%$ & 1 & $6.25 \%$ \\
\hline Total & 16 & & 16 & \\
\hline
\end{tabular}

Frequency distribution of achievement motivation score can also be seen in the diagram below:

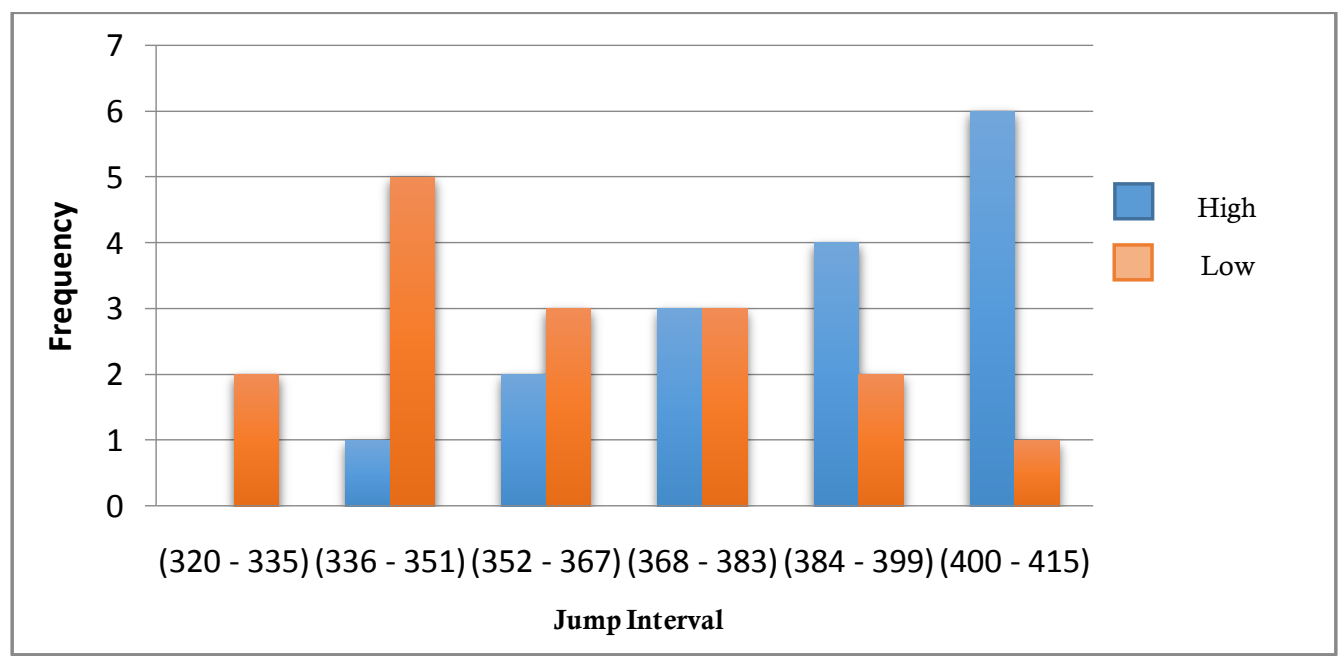

Graph 1. Performance diagram long jump

As a prerequisite test, the analysis performed a normality test, and homogeneity tests data. Normality test to two groups of high jump performance data of the high motivation group with low achievement motivation stated all group data analysis was normal distribution. The homogeneity test of all analytical groups states that all homogeneous analysis groups. Hypothesis testing of research using t-test with $\alpha=0.05$. The results of hypothesis testing analysis from this study are: 
1) There is a significant difference to the performance of the long jump group of high achievement motivation with low achievement motivation.

2) Performing long jumps athlete with high achievement motivation will be better than low achievement motivation.

Achievement motivation is an individual orientation to be able to obtain results as much as possible with the basis to survive and proud to complete tasks that are accounted for him in an activity (Clarasasti \& Jatmika, 2017; Rohsantika \& Handayani, 2011). Athletes with low motivation are also caused by anxious psychological condition before and during the game (Amir, 2014; Kurniawan, 2016; Pramudipta, 2017). Based on the results of research Hutapea found that the motivation of athlete achievement is influenced by the personality possessed by the athlete such as extrovert personality and introvert (Hutapea, 2010). Achievement motivation is also influenced by self-efficacy and social support for athletes (Anggit Sih Lestari, 2015; Choirul Anam, 2007). The athlete's achievement motivation becomes an important capital for athletes to encourage maximum performance during the game (Pramudipta, 2017; Satiadarma, 2000).

Athletes with high achieving motivation can achieve the goal of the exercise well, able to run every activity provided by the coach, and continue to discipline and spirit in the process of training so that it also gives a positive influence upon the ability of long jump. In contrast, athletes with low achievement motivation tend to show serious attitude in training, no discipline in attendance, and often less careful in running the series of exercises, so that the results achieved are also not optimal. From these findings, it can be argued that achievement motivation is very influential in improving the ability of long jump. The higher the achievement motivation of an athlete the ability to jump away will also be better.

In general, motivation consists of motivation from within (intrinsic motivation) and motivation from outside of self (extrinsic motivation). According to Gunarsa motivation can be divided on intrinsic motivation and extrinsic motivation (Singgih \& Gunarsa, 1989). Intrinsic motivation is an impulse that comes from within a person. This urge is often said to be brought from birth. Athletes with intrinsic motivation will follow skills or skill training or follow the game not because of artificial situations (outward encouragement), but because of their inner satisfaction. Self-satisfaction is achieved through the achievement of the goal of the training in accordance with expectations. This person is usually diligent, hard-working, organized, serious, passionate, and disciplined in training. While extrinsic motivation, is the impetus that emerged from a person because it is influenced by factors from outside himself.

Implementation of long jump across the top of several stages. The long jump comprises four phases: prefix, cursory, floating and land. In this study, the researcher will discuss the long jump style of squatting (Yadav, 2015). According to Ballesteros explains, the squat style long-jump results from a horizontal velocity made during the prefix with vertical power generated from the strength at the foot of repel (Ballesteros, 1993). The squat style long jump is one number in the athletic sports whom the participants are performing with the start of a sprint and then jumping with the movement to lift the body from a further point to another. Techniques in long jumps are grouped in several stages.

\section{Conclusions}

Based on the above description of the researcher in this case draw the following conclusions is: a) there is a significant difference in long jump performance with high achievement motivation and low achievement motivation; $b$ ) performance of long jump athletes after with high achievement motivation will be better compared with low achievement motivation. From the results of research and conclusion above, the researcher suggested to: a) for coaches, in an effort to improve long jump performance effectively should use effective training; $b$ ) in an effort to improve the performance of long jump also need to be considered factors that can affect the results from the exercise itself such as motivation, psychology and support parents; c) for researchers that want to research this problem further, so it can consider various limitations to this study, such as the number of samples, sex of the sample and so forth. The goal is to benefit the findings obtained.

\section{Acknowledgments}


Acknowledge anyone who has helped you with the study, including: Researchers who supplied materials, reagents, or computer programs; anyone who helped with the writing or English, or offeredcritical comments about the content, or anyone who provided technical help. State why people have been acknowledged and ask their permission. Acknowledge sources of funding, including any grant or reference numbers. Please avoid apologize for doing a poor job of presenting the manuscript. In this study, the authors get much help and guidance from various parties. On this occasion, the authors would like to thank all parties, both individuals and related bodies that have provided assistance and guidance in the completion of the thesis. In particular, the authors express their gratitude to: a) Dr. Yulkifli, M. Si, Dr. Syahrastani, M. Kes, AIFO, Dr. Willadi Rasyid, M. Pd, as a contributor who has provided input, suggestion, motivation, thought contribution and direction, which is very meaningful both in writing and in testing this thesis; b) Dr. Bafirman, M. Kes, AIFO as the Coordinator of Sports Education Studies Program S2 Faculty of Sport Science State University of Padang that has provided ease and optimal service so that the authors can follow the lecture well until finally complete this thesis; c) Afriyati, S. Pd, as the Principal of SMPN 3 Batang Kapas that has provided facilities in research activities; d) Amir Faisal, S. $\mathrm{Pd}$ and Andri Syahputra, S.Pd as the extracurricular teacher and trainer of Extracurricular at SMP Negeri 3 Batang Kapas who have participated in the research process.

\section{References}

Abbas, I. (2017). Hubungan Motivasi, Kecepatan Lari dan Panjang Tungkai dengan Hasil Lompat Jauh. Jurnal Sport Pedagogy: Program Pascasarjana Unsyiah, 5(1).

Adisasmita, Y. (1992). Olahraga Pilihan Atletik. Jakarta: Depdikbud.

Amir, N. (2014). Pengembangan alat ukur kecemasan olahraga. Jurnal Sport Pedagogy: Program Pascasarjana Unsyiah, 4(2).

Anggit Sih Lestari, A. (2015). Hubungan Antara Dukungan Sosial Akademik Orang Tua Dengan Motivasi Berprestasi Akademik Pada Siswa Kelas Khusus Olahraga (KKO) di SMA N 4 YOGYAKARTA. Fakultas Ilmu Pendidikan.

Anwar, B. N. (2015). Pengaruh Evaluasi Langsung Terhadap Peningkatan Motivasi Atlet Pada Cabang Olahraga Gulat Di Pelatda Jawa Barat Tahun 2014. Universitas Pendidikan Indonesia.

Atmaja, N. M. K., \& Tomoliyus, T. (2015). Pengaruh metode latihan drill dan waktu reaksi terhadap ketepatan drive dalam permainan tenis meja. Jurnal Keolahragaan, 3(1), 56-65.

Ballesteros. (1993). Pedoman Dasar Melatih Atletik. Jakarta: PASI.

Campbell, D. T., \& Stanley, J. C. (2015). Experimental and quasi-experimental designs for research: Ravenio Books.

Choirul Anam, A. (2007). Peran Dukungan Sosial dan Self Efficacy terhadap Motivasi Berprestasi pada Atlit Pencak Silat Pelajar Tingkat Sma/k di Kota Yogyakarta. Humanitas: Jurnal Psikologi Indonesia, $4(2)$.

Clarasasti, E. I., \& Jatmika, D. (2017). Pengaruh Kecemasan Berolahraga terhadap Motivasi Berprestasi Atlet Bulutangkis Remaja di Klub J Jakarta. Humanitas (Jurnal Psikologi), 1(2), 121-132.

Cook, T. D. (2015). Quasi-experimental design. Wiley Encyclopedia of Management.

Ho, H.-M., \& Chang, H. (2013). An iterative expert system for track and field teaching research in the long jump. International Journal of e-Education, e-Business, e-Management and e-Learning, 3(3), 187.

Husdarta. (2011). Psikologi Olahraga. Jawa Barat: Alfabeta.

Hutapea, B. (2010). Studi komparatif tentang motivasi berprestasi pada atlet kempo propinsi DKI Jakarta ditinjau dari keribadian. Jurnal Psikobuana, 1(3), 199-209.

Kamnardsiria, T., Janchaia, W., Khuwuthyakorna, P., Suwansrikhama, P., Klaphajoneb, J., \& Suriyachanc, P. (2015). Knowledge-Based System Framework for Training Long Jump Athletes Using Action Recognition. Journal of Advances in Information Technology Vol, 6(4).

Komarudin. (2013). Psikologi Olahraga Latihan Mental Dalam Olahraga Kompetitif. Jakarta: Remaja Rosda Karya.

Kurniawan, C. (2016). Prestasi Olahraga Angkat Besi Ditinjau Dari Kondisi Fisik, Motivasi Berprestasi, dan Kecemasan (Studi Analisis Korelasi Di Padepokan Angkat Besi dan Angkat Berat Gajah Lampung). Universitas Sebelas Maret.

Linthorne, N. P., Guzman, M. S., \& Bridgett, L. A. (2005). Optimum take-off angle in the long jump. Journal of sports sciences, 23(7), 703-712. 
Martaniah, S. M., \& Monks, F. (1982). Motif sosial remaja Jawa dan keturunan Cina:: Suatu studi perbandingan. [Yogyakarta]: Universitas Gadjah Mada.

Muhajir. (2007a). Pendidikan Jasmani Olahraga Dan Kesehatan Untuk SMA Kelas X. Jakarta: Erlangga.

Muhajir. (2007b). Pendidikan Jasmani Olahraga Dan Kesehatan Untuk SMA Kelas X. Jakarta: Erlangga.

Pradon, D., Mazure-Bonnefoy, A., Rabita, G., Hutin, E., Zory, R., \& Slawinski, J. (2014). The biomechanical effect of arm mass on long jump performance: A case study of a paralympic upper limb amputee. Prosthetics and orthotics international, 38(3), 248-252.

Pramudipta, H. (2017). Motivasi Berprestasi Pada Atlet Tenis Lapangan UMS. Universitas Muhammadiyah Surakarta.

Purba, E. P. (2014). Upaya Meningkatkan Hasil Belajar Lompat Jangkit Melalui Pendekatan Bermain pada Siswa Kelas X-7 SMA Negeri 1 Pematangsiantar Tahun Ajaran 2013/2014. UNIMED.

Rohsantika, N. Y., \& Handayani, A. (2011). Persepsi terhadap pemberian insentif dengan motivasi berprestasi pada pemain sepak bola. Jurnal Proyeksi, 4, 63-70.

Satiadarma, M. P. (2000). Dasar-dasar psikologi olahraga. Jakarta: Pustaka Sinar Harapan.

Septianto, Y. (2015). Profil Kondisi Fisik Atlet Atletik Pusat Pendidikan dan Pelatihan Olahraga Pelajar (PPLP) Yogyakarta Tahun 2015. Fakultas Ilmu Keolahragaan.

Setyobroto, S. (2005). Psikologi Olahraga. Jakarta: Universitas Negeri Jakarta.

Seyfarth, A., Friedrichs, A., Wank, V., \& Blickhan, R. (1999). Dynamics of the long jump. Journal of biomechanics, 32(12), 1259-1267.

Singgih, D. G., \& Gunarsa, D. (1989). Psikologi Olahraga. Jakarta: BPK. Gunung Mulia.

Subowo, E., Martiarini, N., \& Budi, U. S. (2009). Hubungan antara harga diri remaja dengan motivasi berprestasi pada siswa SMK Yosonegoro Magetan. Jurnal Psikohumanika, 2(2).

Syafruddin. (2011). Dasar-dasar kepelatihan olahraga. Padang: Fakultas Ilmu keolahragaan Universitas negeri Padang.

Wakai, M., \& Linthorne, N. P. (2005). Optimum take-off angle in the standing long jump. Human movement science, 24(1), 81-96.

White, H., \& Sabarwal, S. (2014). Quasi-experimental design and methods. Methodological Briefs: Impact Evaluation, 8.

Yadav, M. (2015). Biomechanical analysis of long jump: the hitch Kick. International Journal of Physical Education, Sports and Health, Vol 1, 164-166.

Yani, A. (2015). Pengaruh Metode Latihan Sirkuit, Metode Konvensional dan Motivasi Berprestasi Terhadap Kemampuan Lompat Jauh Gaya Jongkok. Primary, 4(2), 134-142.

Yunus, D., Saripin, S., \& Agust, K. (2018). Hubungan Kecepatan Lari dengan Hasil Lompat Jauh Gaya Jongkok Siswa Kelas IV SDN 009 Parit Teratak Air Hitam Kecamatan Benai. Jurnal Online Mahasiswa (JOM) Bidang Keguruan dan Ilmu Pendidikan, 4(1), 1-13. 